\title{
液体の精密吐出し装置とその応用例 ${ }^{*}$
}

\author{
大 井隆 與**
}

\section{1. まえがき}

現在, 部品の組立工程の中で, 接着, シール, 潤滑な ぞを目的として，一般に液状の材料が使用されている. このような目的に使用される液状の材䉽の多くは，ての

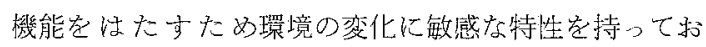

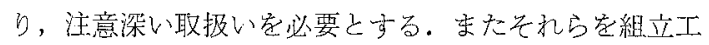
程中に䄧いて使用する場合，その機能を满足させるため に相手部品の形状に合わ世て成形する必要肪あるので, 現状で注嘼産品の組立も含めて，乙れら液状の材料の取 报い注手作業によることが多い。しかし最近の組立技術 の進展にともない，これら一連の作業も組立システムへ の適合性分強く要求されるようになった。そして，さま ざまな材料と, 各種の機器が新しく出現し, 实際に利朋 されるようになった，標記の精密吐出し装置は，その中 でも特㴗求される機器の一つで, 液状の材料の自動供 給つ忘り液状の材料类その容器から一定量づつ計量圧送 し，吖出しノズルにより相手部品に所定の形状に従って 成形することを目的としている。このような装置の例

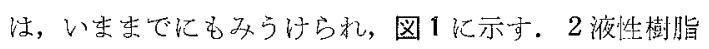

の計量混含吐出し装置(Meter-Mix-Dispensing-System) がその代表的なものである゙1.この他にも，とくに低粘 性（粘性係数 $1 \mathrm{cps} \sim 500 \mathrm{cps}$ 程度）の, 1 液性樹脂の微 量吐出し ( $2 \mu l /$ 回 $0.1 \mathrm{~m} l /$ 回) 目的とした (MicroMeterting-Applicator) $)^{2)}$ とか，高温（約 $200^{\circ} \mathrm{C}$ ) 飞拈 いて液状である樹脂を扱う(Hot-Melt-Applicator) $)^{3) な ~}$ どがある。

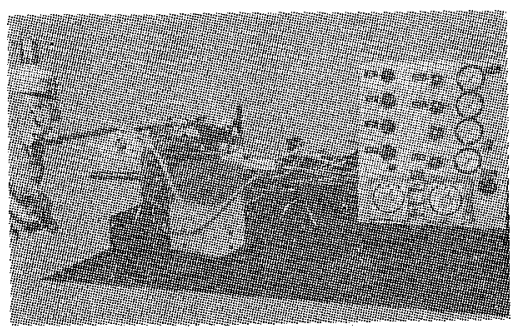

図 12 液性樹脂の訫量混合时出乙装置の例 (Kenics 社)

表 1 にっこれからのべる精密吐壮し装置の慓準的な応

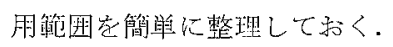

2. 装置の基本的な構成と問題点

表 1 精密吐出し装置の応用範围

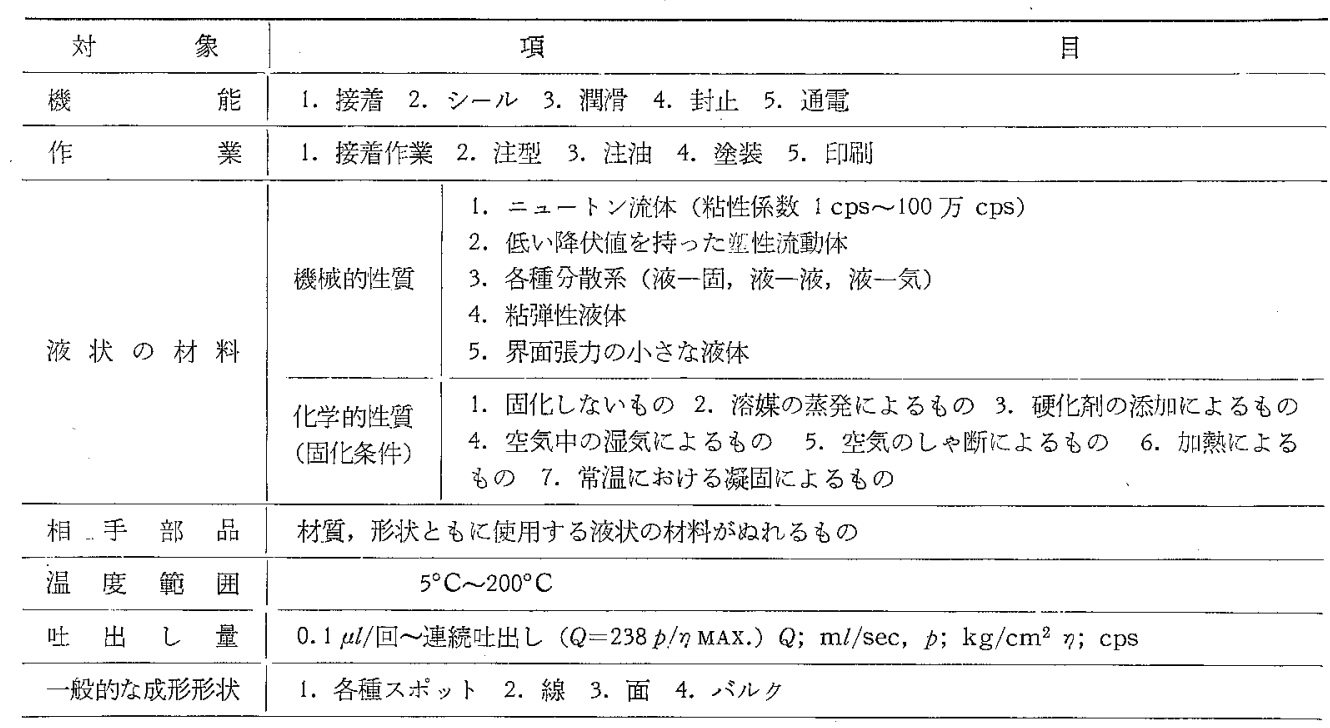

*原稿受付 昭和46年 8 月 9 日. 精機学会自㖶組立專門委員会第12回研究発表会（昭和46年 1 月28日）にて発表. **(㧣)小坂研究所 (埼玉県北葛飾郡三郷圢久兵衛) 


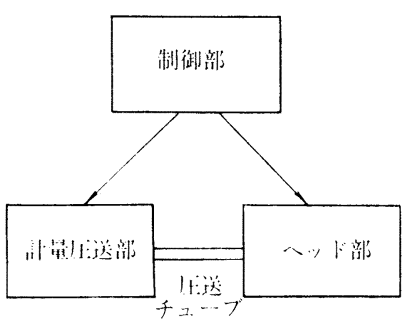

图 2 精密比出し装置の基本的な構成

精密吐出し装置は, 基本的に図 2 に示すごとく, 計量 圧送部と, 液状の材料の成形に関与するへッド部さらに それらを接続する压送チューブ，そして制御部から構成 されている，装置における接液部の基本的な特性は，1） 液状の材料に対して化学的に不活性であること，2）非

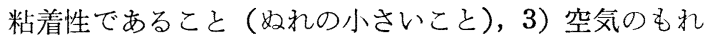
や, 液のもれのないこと，4）液の流れに停滞のないこ となどである，これらを満足させるため，液の流路はノ ズルを含めて円管の連続体で構成されている．またこの 装置は, レイノルズ数 $R_{e}<10^{2}$ の状態で使用されること がほとえどなので, その流量 $Q$ は, ハーグン・ポアジュ ィユの法則 $Q=\pi \cdot\left(P_{1}-P_{2}\right) a^{4} / 8<\eta$ を参考にして求めら れる。

そこで，この式をもとにしていぎに計量生送部の基本 的な構成と, 問題点を考察してみる.

\section{1 計量圧送部}

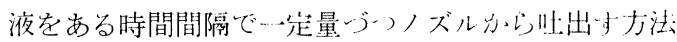

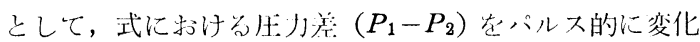

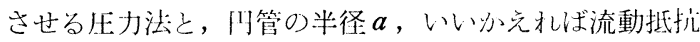
を変化させるバルブ法とが考えられる。そこでもし，こ のパルス的変化の積分值が一定であれば吐出し量 $\int Q(t)$. $\mathrm{d} t$ は一定になるが，このとき $\left(P_{1}-P_{2}\right), a$ のほかに， 円管の長さ $L$ 粘性係数 $ク$ が一定である条件を满さなけれ ばならない。もしこれらの值のどれか一つでも変化する ならば压力法, バルブ法とは別に，その変化をほとんど 無視できる計量圧送方式が必要となる。特殊な場合なら ば，王力法やバルブ法の構成学閉ループにして吖出し量 を一定にコントロールできるが，開ループでは，プラン ジャポンプのようないわゆるポジティブ・ディスプレイ スメントポンプを使䏘多を、いずれにしても，精密战川 乙装置は, 液状0材料の特性, 叶将乙㫣乙そ0精度, 心

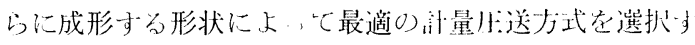
ることが必要である。

\section{2 ヘッド部}

計量圧送部から压送された液注ノズルから喷出あるい は押し出され，相手部品に付着しながら所定の形状に成

形されるが，この成形に関与する部分をへッド部と呼ぶ ことは前にものベた.

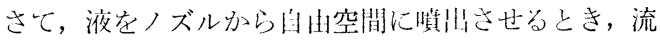
速を増加させるに徉って，図３に赤すとおり単一滴化の 状態から層流からの滴化, 乱流からの滴化を経て, 噴霧 流となる4.

そこで，精密吐出し装置ではどい噴流状態を利用す べきかが問題となる。そこでこれ簡単に整理してみる と,まず単一滴化の状態では, 压送に要する動力は小さ いが，液滴のコントロールが困難で，とくに表面張力の 小さい液の場合ノズルの外側に浮き上るなどの欠点があ る。層流からの滴化は，その噴流のパルスの立ち上りと 立ち下りの特性が直角ならば，層流部における流れの太 さ, 方向が安定しているので, 吐出し量のコントロール および成形が容易となる. 乱流からの滴化および噴霧流 は, 流出に大きな動力を要すること, 流れの方向のコン トロールに難があるなどの理由で，特別の場合以外は利 用できない, 要するに, 精密吐出し装置に利用しうる噴 流の状態は, 層流が適当である. 理想的には, パルス状 の一次元流ということになる.

つぎに, 精密吐出し装置は, 液状の材料をノズルから 相手部品つまり沽体面に向けて吐き出すので，上にのバ た肖由空間への噴流モデルよりも，壁面噴流モデルとし てあ亦うことがより実際的な場合が多い。たとえば，

図4 に示す去打り，ノズルと固体間が十分接近している とすをと，単一滴化の状態が存在しないこ上は明らか心 あ气。として，ズルから流壮与る液が周体面に付着 し，一定速度で流机\%か，または流れない場合，沽体面 がその面に平行に一走速度で運動すれば, 液は連続流と なり，前にのべた層流と等価になる。つまり液の固体へ のぬれのエネルギあるい注，ノズルと固体面の相対的な 移動による運動エネルギによって，ノズル先端における エネルギ交換が行なわれ，単一滴化のような小さな流出 の動力で, 液の固体面に打ける連続流机, つまり層流を 実現することができる。このほかにも，ノズルに打ける エネルギ交換によって, 液に特殊な流動を与えるさまざ

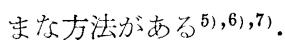

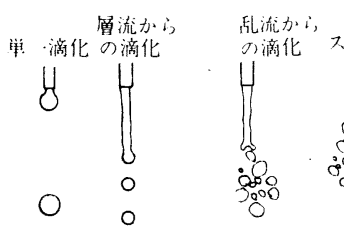

图 3 ノズルから自由空間へ 墳出する液の流速によ る変化の様子

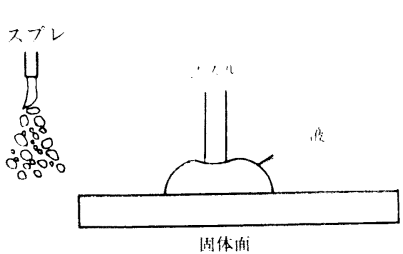

図 4 ノズルからの固体面へ の噴出モデル 
ヘッド部において，さらに重要な問題がある。それは ノズルと相手部品との湖に付着している液状の材料の切 れの問題である。一般にこの切れは，ノズルと相手部品 ○閒にある液が流動して，しだいに細い系状にのびてか らついに切れることが観然さ机る8 法, 界面張力でノズルと相手部品の両施に引きもどさ れを。この引きもどされた液のうち，相㐿部品側に付着 与るものは，成形形状を不安定に与る原因となる。また ノズル側に引きもどされたものは，そのままノズルに留 るので, これが固化するような液状の材料の場合, 部量 精度を低下させるばかりでなく, 吐出し不能になる場命 もある。そこでノズルに打る液の切れをコントロール する必要があるわけであるが，その具体的な方法は液状 の材料の特性とか成形形状などによって異るので，この あとの構成要素の項でのベることにする.

\section{3. 精密吐出し装置とその構成要素}

精密吐出し装置の基本的な構成は図 2 に示したと㧍り であるが，その具体的な構成要素は，使用与る液状の材 料, 成形形状により異なる. 以下にそれらを説明する。

\section{1 計量圧送部の構成要素}

3.1 .1 ポットタンク

ポットタンクし構造老図 5 にパす。こ扎はポリエチレ ンあるい紙ニップなどし簡単な容器 (Pot)に貯蔵され

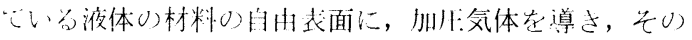
ピストン作用によ，て液圭归送チュープに押し中方式

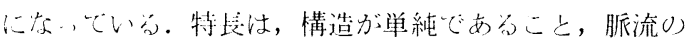
ないこと势ずあげら机。，尔点は，ピストンが父体な ので，厓絡性があり，また液中にとの父体が溶解するこ とである。また溶器中の液がなくなった場合，左送を一。 時停止して液体を補充しなけれ流ならないので, 容器中 の液量を検出することがある。また，タンクのふたの開 閉が容易にできる工夫がなされている.

\section{1 .2 カートリッジタンク}

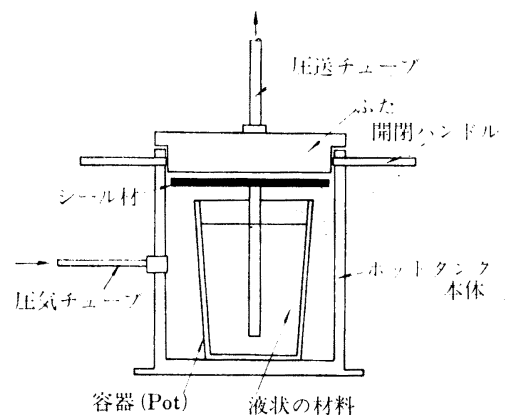

图 5 ポットタンク

液状の材料が塑性を示醋全，ポットタンクでは液を 完全に押し出すことができないので，固体のピストンに よ，て液定押し壮すカートリッジタンクが使用される。 こ机注，液中へ0気体の溶解老防止与る効果もある。な 打塑性定示主液を哀器から谷器へ移しかえるとき, 空気 茬だき込むことがある。そのためにノズルの部分などで 液が，空気により分割され棓量精度を著しく低下させ る。こ札它なくするために，特別な気体の分離装置を必 要とする。.

\section{1 .3 并}

㓩にのベたバルブ法では，压送タンクとノズルの間に 升を設ける。また，压力法でも計量精度を向上させるた めに弁を使用することが多い。この弁の種類としては, 瞬間に流路を開閉する自動式の弁と, 手動式の弁および 流量調整弁がある. そして刍動式の弁には空気圧で操作 卉る空圧弁と，とくに高速度の開閉を行なうための電磁 弁とがある.さらにこれら開閉のための弁注, 開閉時に おける液の流孔かた，とくに立七下り特性によって 3 種 類に分類される。

1)開路時には下流の液芜引き込み，閉路時に押し出す 特性を持つ弁.

2)トとは逝に，閉路時に下流の液を引き込む弁。

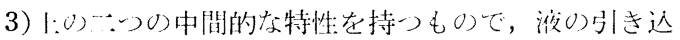

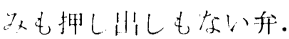

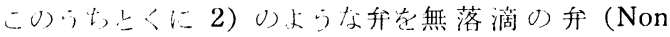
Drip Valve, Dripless Valve)し呼んで抢り，液のノズル

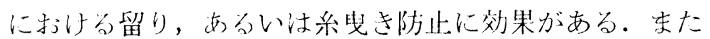

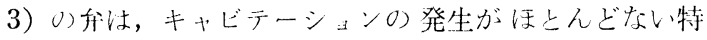
主花持,てい首。

こ机らの升は，二ードル亣，スプール升，ダイヤフラ ム弁，ピソチ厽などを志用したものである ${ }^{91}$. 図 6 に二 一ドル热とスプール弁を複会した無落滴の弁の一例を示 -510).

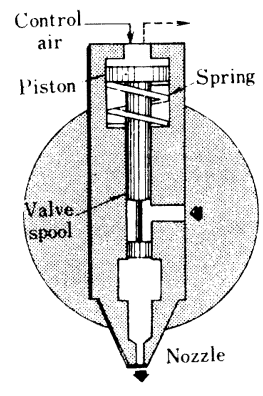

图 6 無落滫のバル ブの例
ただしこの形式のものは，い わゆる瞬間接着剂などに使用する ことができない，そこで特殊な無 落滴の弁䘮使湖し，ノズルにおけ る液の留り在防止している。

䉼性倸数の小さい液状の二_トン流体を計量左送する場合，目 然水顛 (Natural Head) の変化に 上，て叶出し量が除々に小さくな てていくことが観祭される。この 現象をなくするには，流量調整升 で流路を細くし，毛細管現象など 
によるヒステリシス安大きくすると効果がある。

また流量調整弁汪，一ののタンク加ら同㭙に複数の， ボルをだし，そ机ぞれの时壮し量のバランス安とるとと に使用される。

\section{1 .4 圧送チューブ}

圧送チューブは，いままでのべたタンク，弁，さらに これふらのベるノズルなどの各構成要素連結するもの であるが，すくなくとるつぎにあげるよらな性質在持っ ていなければならない。

1)液状の材料に対する耐性があること。

2)洗浄用の溶媒などによる膨潤のないこと.

3)圧送チェーブ自体がいわゆるアキュムレータになら ないこと.

压送チュープの材質㤝，ポリエチレン，ポリプロピレ ン, TFEなどで, 内径 $2 \mathrm{~mm}$ から $4 \mathrm{~mm}$ 程度のものが よく使用される。

\section{2 ヘッド部の構成要素}

\section{2 .1 ノズル}

ノズルは，ステンレススチールのパイプと各種の高分

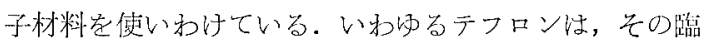
界表面偯力分18程废で，高分子材料の中でも小さいため ノズルにおける液の留りあるい液の浮き上り定減少さ 过尚ととがある。しかし，带電性の点で問題がありステ ンレススチールのノズル定使用与ることも多い。ただ し，金属イオンにより重合を開始する液の場合注，高分 子材料のノズルを使用すべきである。また，高分子材料 のノズルの多くは，䢛度な柔軟性がありそれを成形法に 利用与ることもできる。

\section{2 .2 ノズルブロック}

戞糸性 (Spinnbarkeit, Thread Forming Property) 㒸示す液の系曳きの防止，あるいはたれの防止にノズル 定特別な構造にすることがある。安た同㭙多点吐出しの 場合ノズル学何本も使用する。このために使用卞尚ノズ ルの保持具它ノズルブロック乙呼えでいる。 ノズルブロ

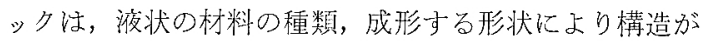
異なるので，数多くの種類がある，てこで，こてでは糸 曳き防止に使用されるノズルのうち，いくつかの構造学 説明守る。

“系曳き”あるいは“たれ”安示す液状の材料として， 粘性係粘の大きな液（大体 $10000 \mathrm{cps}$ 以上）あるいは， 粘弾性液体なご11がある。さらに史いた糸は，時間が経 過すれば自然に切れるものと，僢間的に糸が固化してし まって，時間が経過しても切れないものとがある。後者 の糸は，とくにエラストマの接着剂に見られるもので， 数メートルも伸びてはじめて切れ，あるい注破壊する。

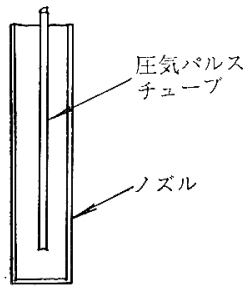

図 7 圧気パルスによ る糸切りノズル の楧成

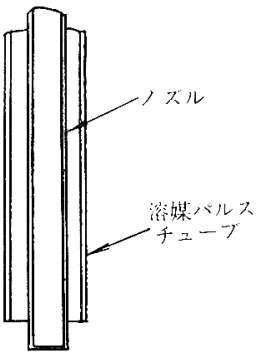

図 8 溶液のパルスに よる采划りノズ ルの構成
図 7 は，固化しない糸の糸切りノズルで，ノズルと相 手部品の間にある液に気体のパルス劣送りこみ，それと 同時にノズルを逃がして，系曳き学防止与る構造になっ ている. 図8 は同㥞に, 液の閒にその液の良溶媒のパル 又定送込み，固化する系の系曳き越止するノズルの構 造定示している。なたノズルの先端安 1 国の昍出しごと に自動洗浄与ることもある。

\section{2 .3 ノズル操作装㯰}

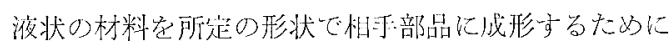
ノズルの位置決め，和よび移動安行なら必要があ名。こ のための装䈯苍ノズル操作装䈯と呼んでいる。

ノズルの操作龙于作業でするには，ペンシルタプあ るいはガンタイプのノズルブロックホルダ定使用する。. とくにガンタイプのホルダは，卜リガスイッチがあり， エハルスで一䇥量あるいは任意の量の时屾しができる

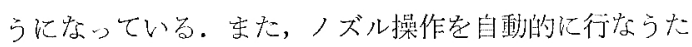
めのいくつかの基本的な動作を方台ニニットが使用され る.たとえば，ノズルに上下動，前後動，円運動さらに それら定複合した運動安与えるもので，上下動大名ン ド，前後動テーブル，サークルユニットと呼えでいる。

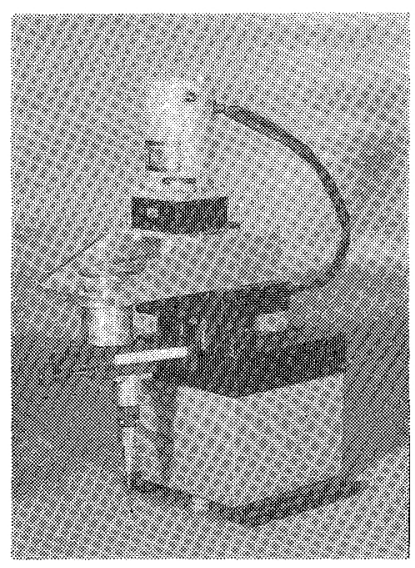

図 9 サークルコニット サークルユニット究 図9に示す。こりほ か飞組立システム にあるせでズルに 特别度運動庆与克当 ことが多い。

\section{3 制御部の構} 成要素

制御部の構成瑟素 は各種モジュール化 されている。兵扎を 表 2 に示夺。委た制 御部の一例笓図10k 示宁. 
表 2 制御部のモジュール

\begin{tabular}{|c|c|c|c|}
\hline \multicolumn{2}{|c|}{ 制御対象 } & モジュール名称 & 具体的な制御 対 象 \\
\hline 時 & 間 & $\begin{array}{l}\text { タイマモジェール } \\
\quad(0.1 \sim 60 \text { 秒 })\end{array}$ & $\begin{array}{l}\text { 1. 弁の開路および閉路時間設定 } 2 \text {. スキャナの停止および運動時 } \\
\text { 間設定 3. タンク加圧時間設定 }\end{array}$ \\
\hline \multirow{3}{*}{\multicolumn{2}{|c|}{ 力 }} & $\begin{array}{l}\text { レギュレータモジュール } \\
\left(2 \mathrm{~kg} / \mathrm{cm} \sim 7 \mathrm{~kg} / \mathrm{cm}^{2}\right)\end{array}$ & $\begin{array}{l}\text { 1. タンク圧力設定 2. 弁開閉力設定 } 3 . \text { スキャナ駆動力設定 } \\
\text { 4. 系切りパルス高さ設定 }\end{array}$ \\
\hline & & $\begin{array}{l}\text { 圧力検出モジュール } \\
\left(0.1 \mathrm{~g} / \mathrm{cm}^{2} \sim 5 \mathrm{~kg} / \mathrm{cm}^{2}\right)\end{array}$ & $\begin{array}{l}\text { 1. 液量レベル検出 } 2 \text {. 糸切り終了検出 } 3 \text {. 吐出し量検出 } 4 \text {. 相 } \\
\text { 手部品位置検出 }\end{array}$ \\
\hline & & $\begin{array}{lcr}マ & \text { ク } \\
\text { スイッチモジュール }\end{array}$ & 1. タンク内液量検出 2 . スキャナ停止位置検出 3 . 吐出し量検出 \\
\hline & \multirow{2}{*}{ 度 } & $\begin{array}{l}\text { 加熱器 }\left(40^{\circ} \mathrm{C} \sim 200^{\circ} \mathrm{C}\right) \\
\text { 冷 却 器 }\left(5^{\circ} \mathrm{C}\right)\end{array}$ & タンク, バルブ, ノズル, チューブの温度設定 \\
\hline & & $\begin{array}{l}\text { 温度補償モジュール } \\
\left(5^{\circ} \mathrm{C} \sim 40^{\circ} \mathrm{C}\right)\end{array}$ & 温度による粘性係数変化の補償 \\
\hline 速 & 度 & $\begin{array}{l}\text { 速度設定モジュール } \\
(5 \mathrm{~mm} / \mathrm{s} \sim 100 \mathrm{~mm} / \mathrm{s})\end{array}$ & スキャナ運動速度設定 \\
\hline 光 & 量 & 光量検出モジュール & $\begin{array}{l}\text { 1. 液量レベル検出 } 2 \text {. 液体検出 } \\
\text { 3. 相手部品位置検出 }\end{array}$ \\
\hline 演 & 算 & 演 算 モジュール & $\begin{array}{l}\text { 1. 吐出し回数設定 2. 時間の経過による粘性係数変化補正 } \\
\text { 3. 吐出し量設定 }\end{array}$ \\
\hline
\end{tabular}

図表

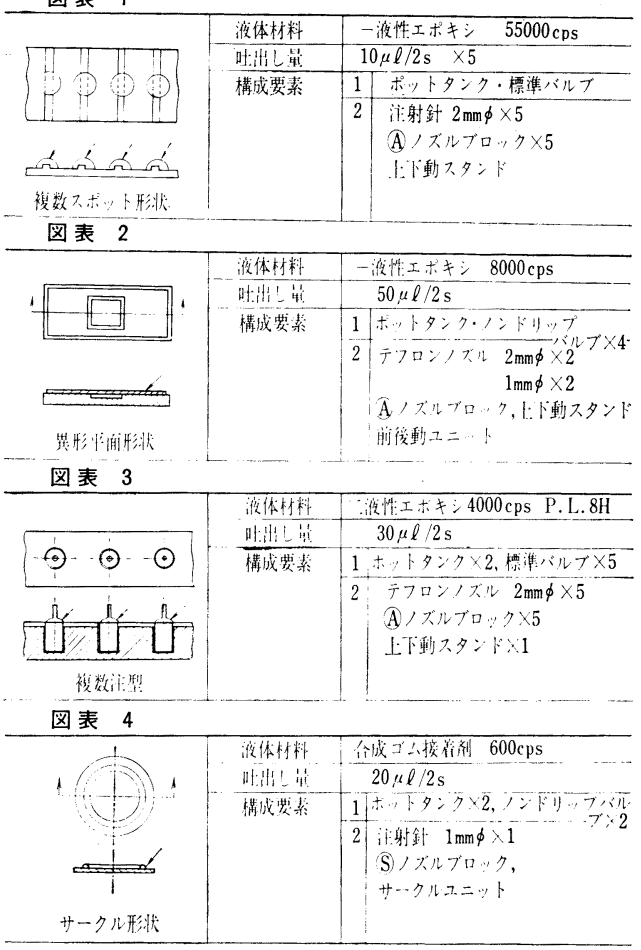

図表 5

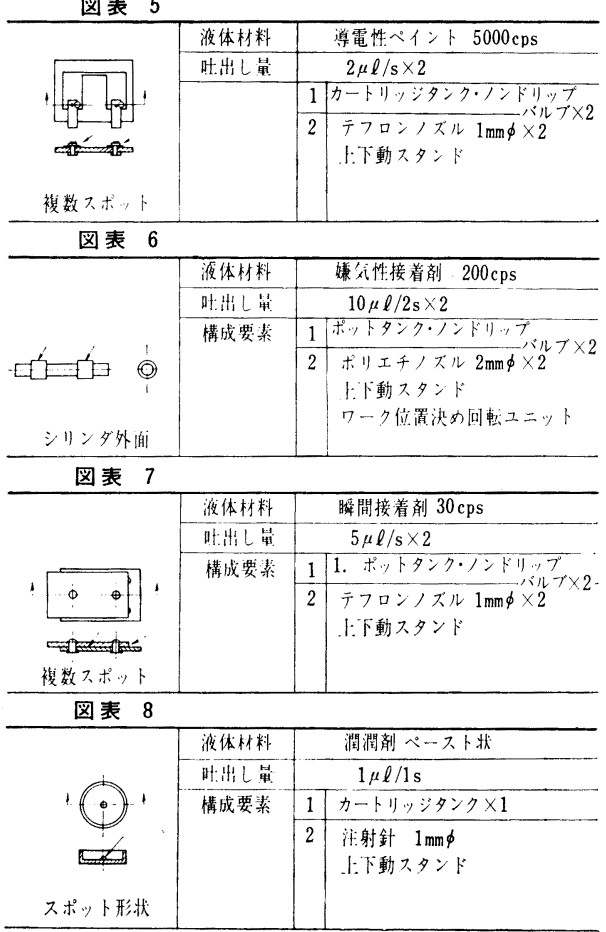




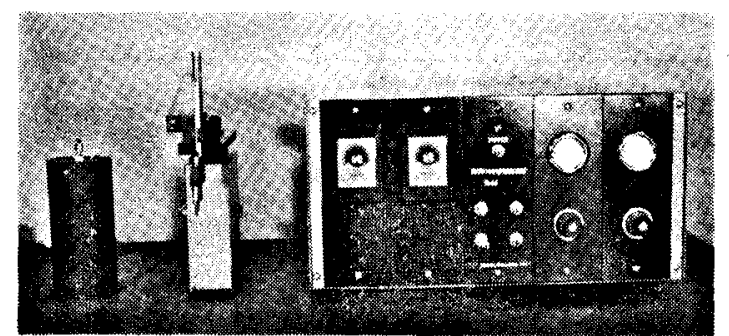

图 10 制御部之計量圧送部, ふッッド部の組合せ例

\section{4. 応用例}

代表的な応用例を図表 1 から図表 8 までに示す。

\section{5.あとがき}

固体の部品に，主に液状の材料を自動的に成形固化す る代表的な機械の一郡に印刷機械がある。この印刷機械 は，これまでのべた精密吐出し装置と同じように主に液 状の材料と固体の相手部品を組合せる装固であるが印刷 機械では, 液状の材料, 相手部品の材質, 形状さらに成 形形状を高度に選択している。それに比較して精密吐出 し装置は，それらの選択が低級であるといえる，ともか く，円管ノズルによる液状の材料の相手部品への成形で
留意すべき点は，分割性のよい一次元流を実現し，それ を利用することである，しかし実際には，精密吐出し装 置で処理すべき液状の材料の種類が多く、いままでのべ たような装置の構成要素は現在増加している状態で, な かなか減少しない，そして組立システムへの適合性を増 大寸るために，これまでのべた液状の材料とは別に，固 型状,フィルム状，マイクロカプセル状の材料も多く利 用されている。組立システムの合理化が要求される現 在，本交がそのシステム計画の一助になれば幸いであ る.

\section{参考文献}

1) Pyles 社, Graco 社, Kenics 社, 東京オートメーション 社：カタログ.

2) Loc-Tite 社, Kenics 社: カタログ.

3) Nordson 社, Spraymation 社, 明製作所: カダログ.

4) 宝沢, 只木, 前田: 化学工学, 33 (1969) 893.

5）神保：振動測定，精密機械，32，7 (1966) 514.

6) 浅野ほか: 水力機械工学便覧, コロナ社 (1957) 254 .

7) ランズパーグ社, カシオ社：カタログ.

8）中川:レオロジーとはなにか, みすず書房.

9) Carl B. Penn: Dispensing Liquid Accurately, Automation Dec. (1965).

10) 藤永, 岡: 自動滴定, 誠文堂新光社 (1964) 51 .

11）たとえば中川：レオロジー，岩波全書， 249 (1969) 228 . 